\begin{tabular}{l|c|c} 
Journal of Social Studies Education Research & \\
Sosyal Bilgiler Eğitimi Araştırmaları Dergisi & 2017:8 (2), 62-79 & \\
\hline
\end{tabular}

\title{
Transformation of Approaches to Organizing the Students' University Practical Training in the Area of Social Activity: A Post-Soviet Experience
}

\author{
Ekaterina O. Akvazba ${ }^{1}$, Lyudmila K. Gabysheva ${ }^{2}$, Pavel S. Medvedev ${ }^{3}$, Natalya I. Skok ${ }^{4}$, \\ Tatyana E. Ukhabina ${ }^{5}$
}

\begin{abstract}
The relevance of studying the problem is conditioned by a number of circumstances existing in the Russian social education. Among the most important ones, the following should be named: having to bring the Russian education close to and harmonize it with the European one in line with the Bologna requirements, the need to overcome its excessive academicism, as well as the actual performance of the long-proclaimed transition to practice-oriented learning. The objective of the paper consists in suggesting the variants of overcoming the existing controversies and disadvantages of the professional training of social activity specialists by putting forward a model for organizing the practical training in the direction of "social work". The model includes the concept of practical training and mechanisms for implementation thereof in the modern Russia with the experience of the European countries borne in mind. The leading approach to the study of the problem was the method of hypothetic and deductive modeling, including all the successive stages up to the experimental one. The paper presents the results of theoretical analysis of scientific and methodological sources on the problem of practical training and implementation of practice and activity-oriented education at the Russian higher education institutions which is aimed at personal and professional development of students via the formation of competences. The analytical approach allowed identifying the key organizational disadvantages that prevent the said approach from being implemented to the full extent in the Russian education practice, including due to the lack of an optimum practical training model. The results of the research have allowed providing grounds for having to develop the concept of students' practical training in social directions of activity and suggesting the mechanisms for implementing it at the Russian educational organizations. The materials of the research can be used by the Russian and foreign higher education institutions when holding the students' practical training, first of all, in the area of social work.
\end{abstract}

Keywords: transformation of Russian education, traditional paradigm of education, competency, competency-based approach, practice-oriented model, the concept of students' practical training in the social education.

\footnotetext{
${ }^{1}$ Assoc. Prof., Candidate of Philology, Industrial University of Tyumen, kitino@ mail.ru

${ }^{2}$ Department Director, Candidate of Sociology, Industrial University of Tyumen, gabyshevalk@tyuiu.ru

${ }^{3}$ Assoc. Prof., Candidate of Pedagogy, Industrial University of Tyumen, korolallemonda@mail.ru

${ }^{4}$ Prof., Doctor of Sociology, Industrial University of Tyumen, natalya-skok@mail.ru

${ }^{5}$ Assoc. Prof., Candidate of Sociology, Industrial University of Tyumen, klever_te@mail.ru
} 


\section{Introduction}

The Russian fundamental education was created upon the knowledge-based paradigm. For several decades, the educational process in the system of general and professional education has been built on the deductive basis in line with the didactic triad "knowledge - abilities skills", with the principal attention paid to knowledge acquisition. It has been believed that the very knowledge acquisition process has a developing potential: it is during the process of learning that the required abilities and skills have to be formed (it is sufficient to recollect the developmental learning theory). The many years practice has found essential disadvantages of such an approach.

A comparative study of the quality of education with higher education institution graduates of post-Soviet countries (Russia, Belarus, the Ukraine) and the developed countries of the West (the USA, France, Canada, Israel) conducted by the World bank registered that our students show very high results (9-10 points) in the "knowledge" and "understanding" criteria and they score very low in the "practical application of knowledge", "analysis", "synthesis" and "evaluation" ones (1-2 points). Meanwhile, the students from other countries have shown quite the opposite results, i.e. they have demonstrated a high extent of development in skills of analysis, synthesis, and decision-making abilities against a relatively low level of the "knowledge" parameter.

Among causes of crisis of the traditional education paradigm, they also list the information getting obsolete under the modern conditions much faster than the natural education cycle at the secondary and higher school is completed. Consequently, the traditional orientation to transferring the required knowledge reserve from teachers to students ceases to make sense. What is much more important is to teach the students the abilities to acquire knowledge. Moreover, at the labor market, it is not the knowledge as such that are in demand but a specialist's ability to use them in practice and to perform certain professional and social functions.

Russia's system of higher professional education is currently undergoing profound change that is closely associated with the change in economic, social and political, cultural spheres of life of the society. The change makes the university education face the necessity of a new comprehension of its essence, the principles of organization and management. The main task for teachers of the modern higher school is to generalize the positive experience of the total of 
pedagogical technologies, approaches and techniques that used to be applied before and to build the foundations for renewal of the pedagogical paradigm in order to upgrade the content of higher professional education on its basis. The change of the pedagogical paradigm actualizes the new basis categories in the content of education - the competences.

The competency-based approach emerged as an alternative to the abstract and theoretical knowledge and at present is increasingly actively being introduced into the pedagogical reality. Within the competency-based approach, there is an attempt to implement the personality orientation of education, its activity-, practice-related and cultural components while keeping the fundamental and universal character.

The competency-based approach is oriented first of all to the achievement of certain results and acquisition of meaningful competences. As for competences acquisition, this is impossible without gaining an experience of activity, i.e. competences and activity are inseparably connected. Competences are formed in the process of activity and for the sake of the future professional activity. Under these conditions, the process of learning gains a new meaning - it turns into the process of studying/acquisition, i.e. acquiring the knowledge, abilities, skills and the experience of activity in order to achieve professionally and socially important competencies.

There are several approaches to practice-oriented education within the system of higher education. Some authors associate it with organizing the students' educational, on-the-job and pre-graduation training intended to plunge the students into the professional environment, to make them correlate their ideas about the occupation with requirements put forward by actual business, and comprehend their own role in social work. Other authors consider the implementation of professionally oriented learning technologies that promote the formation of personal qualities that are significant for the future professional activity as well as knowledge, abilities and skills ensuring a high-quality performance of functional duties in the specialty of one's choice to be the most efficient. Yet, other authors associate the rise of practice-oriented education with using the opportunities of professionally oriented, context learning of profile and non-profile subjects (Lopatin, 2008).

Unlike the traditional education that is oriented to knowledge acquisition, the practiceoriented one is aimed at gaining the abilities, skills and experience of practical activity alongside with the knowledge (Mauch, \& Tarman, 2016). However, education cannot be practice-oriented 
without gaining the experience of activity (Degterev, 2008).

\section{Literature Review}

It is widely acknowledged worldwide that it is the activity- and competency-based approach is the strategic foundation for the entire modern educational system: by Martincová \& Andrysová (2017); Erbilgin (2017); Kenna \& Poole (2017), Mathews (2016); Paleeva, (2013); Demchenkova (2011); Eremina, Zoroastrova and Suchkova (2015); Sitaeva \& Chupris (2015); Auvinen (2006); Zeer (2000); Zimnyaya (2003); White (1959). Interestingly, it was E. Toffler's statement that became one of the impulses for the development of competency-based direction in education; in his work "The Futurists", he remarked that "knowledge is becoming increasingly complicated. What today is a fact then becomes a mistake. Students must learn to reject old ideas, to know when and how to replace them. To put it short, they must learn to learn, unlearn and relearn. An illiterate person of tomorrow will be not the one who cannot read but the one who has not learned how to learn" (Toffler, 2002, p. 46).

The idea of the content and structure of a modern man was supported by R. W. White (1956). He not only described the competences but also suggested a system for assessing these with forecasting the graduates' professional and personal prospects taken into account.

Speaking about the latest works on competences, the studies by Soland, Hamilton and Stecher (2013) should be mentioned which identify the key competences of the $21^{\text {st }}$ century: cognitive ones, intra- and interpersonal ones.

The main idea of competences consists in their being closely associated with a specialist's process of activity (Social psychology of education, 2005). As it is stated by many scholars at present there takes place a certain loss of clarity and completed outlines of professions, the flexibility of the labor market emerges, and identification of stable specialties is lost while they gain the nature of dynamic short-term "packages of competences". The dynamic professional character comes to replace the stable occupations. Qualifications and competences do not contradict each other but they represent various aspects of personality- and activity-based potential. It is the temporary and unstable nature of professions that can be seen as a working model of the future.

Thus, it is a broad view including addressing to the future labor markets that is inherent in the competency-based approach. Meanwhile, it should be pointed out that the general transition to the two-level higher education consolidated by Bologna agreement and actively supported by 
first of all Western specialists, in particular, by Teichler (2005), has regrettably failed to yield the expected results so far.

For instance, a research conducted in Germany showed that the degrees obtained are not always recognized. During the study conducted after the introduction of bachelor's and master's degree, 2135 enterprises of the German congress of industry and commerce gave their first appraisal of the higher education institution graduates. The following facts were found out during the survey:

- Almost $40 \%$ of the enterprises parted with an employee hired right after graduation already during the trial period. Most frequently - in $26 \%$ of cases, they named as the reason the new employee's being incapable of applying the obtained theoretical knowledge in practice.

- Only a quarter of the enterprises surveyed have already had an experience of working with graduates having a bachelor's or master's degree.

- Do the bachelors live up to the employers' expectations? A third of the enterprises respond in the negative. Two thirds think the bachelors are up to their expectations. The fact has to be considered as a signal of the new organization of the leveled system of higher education not quite succeeding yet.

In Germany, the criticism also touches upon the question of specialty knowledge: almost $40 \%$ of the enterprises complain about the graduates' insufficient knowledge in their specialties, about a third criticize the absence of methodological, social and personal competences (Heimann, 2008).

In spite of that, it is the competency-based approach that remains the principal tool that allows modeling the results of education and their representation as the standards of quality of the higher education, which means the following:

- the results of education being reflected in a systemic and integral way;

- the results of being educated at higher education institutions being worded as signs of readiness of a student/graduate to demonstrate the appropriate knowledge, abilities, skills and values;

- the structure of competences to be acquired and shown by the learners being determined, the competences being adjustable in conditions of the regional labor market.

Special attention when implementing the competency-based approach in the professional 
education should be paid to the multi-variability of the model, to its taking into account the particularities of development of the future specialist's sphere of activity.

By the model of a specialist, a certain image to be achieved during the process of training at higher education institution and to be up to the modern requirements is understood. The development of the model of a specialist allows making more precise the objectives of specialists' training, correcting the curricula and programs, selecting the methods and means of learning that are relevant to the specialist's activity as it is meant to be in actual conditions, elaborating more grounded solutions for enhancing the efficiency of students' professional training (Haedrich, 1967).

Thus, it is the competency-based model of a graduate that becomes at present the systembuilding element of the content and result of education (Hoffmann, 2017). It is the model that is a foundation for developing the conceptual approaches to organization of practical training. The said viewpoint is shared and supported by many Western specialists, in particular, by Kolb and Kolb (1984); Doel and Shardlow (2004); Schmitt (2007); Merten (2000).

In the professional and personal model of a graduate, the objectives of education are associated both with the objects and subjects of work, with performance of certain functions, and with interdisciplinary integrated requirements for the result of the educational process.

A further opportunity for the relevant adaptation of the best practices available in the European Council countries was the transition of the Russian education to the activity- and competency-based model and Bologna principles.

Thus, the main task of the upgrade of education is having to adapt the content of education, learning technologies and practical preparation for the needs of the labor market, as it is the latter that determines the set of competencies required for a graduate.

\section{Materials and Methods}

Taking into account the high importance of practical training for the higher education institution graduates' professional activity, the research group - the authors of the paper - have conducted the theoretical analysis of printed publications, methodological materials, the foreign experience of organizing and conducting the practice when training the social activity specialists. The objective of analysis was to determine the conceptual provisions in preparing, conducting, and organizing the practical training, making its goal orientation and assessment methods more precise. The main task the researchers faced was to dissect in detail the current laws and 
regulations of all levels (the federal, the regional and the local ones), methodological materials, mostly those of the RF Ministry of education and the RF higher education institutions (Tyumen Industrial University, Ural State Pedagogical University) as well as the foreign higher education institutions (Lüneburg University - Germany, universities of Finland and the Netherlands) on the organization of practical training of students enrolled in social directions of training (social work, social pedagogy), and to study the experience of the institutions in the sphere of educational activity (Verein für öffentliche und private Fürsorge e.V., 2004, Bundesarbeitsgemeinschaft der Praxisämter, 2005, 2006, Jugendministerkonferenz, 2006).

The analysis encompassed the curricula, working programs of practice-oriented subjects, competency-based models of graduates, the competences formation assessment systems, provisions on practical studies, practical assignments, the report documentation on the results of undergoing the practical training, and practice management. Alongside with the analysis of the data sheets, opinions and the experience of practice organization at various higher education institutions were exchanged.

As a result of the work conducted, the concept of students' practical training has been developed, with the competency-based approach underlying as it was adopted as the initial one by all researchers.

\section{Results and Discussion}

The logics of the analysis conducted, the literature sources available and the data sheets listed predetermined the task of the first stage of development of the concept of students' practical training in the direction of social activity. The essence of the task consisted in building a professional and personal model of a graduate where the objectives of education would be associated both with the objects and subjects of work, performance of competences, functions, and with the methodological standards, integrated requirements for the results of the educational process. Competences and the results of education act as an integrating principle in the model while the basis of the professional and personal model is made up by the systemic and activitybased approach, which is the most characteristic one for the Russian higher school. The components of the professional and personal model are up to the thesis "a graduate's readiness for the professional activity consists in the graduate's acquisition of a complete set of social knowledge, professional actions and social relationships as well as in the completed formation and maturity of the professional and personal qualities of the individual" (Ukhabina, 2008, p. 
197).

The professional and personal model of a graduate contains components represented by levels, competencies and competences. In the hierarchical structure of the model components, each lower level is characterized by what the levels located above it are determined. Proceeding from these standpoints, three main groups of competencies in the professional and personal model of a graduate have been isolated: the professional and subject-related competency; the professional and activity-based competency; and the professional and personal competency.

According to the diagram suggested, the structure of the professional and personal model of a graduate studying in the direction of social activity can be presented as follows in Table 1 "The structure of professional and personal model of a graduate studying in the direction of social activity".

Table 1

The structure of professional and personal model of a graduate studying in the direction of social activity

\begin{tabular}{|c|c|c|}
\hline Competencies & Criteria (approximately) & \multirow{4}{*}{$\begin{array}{l}\text { External assessment of the } \\
\text { professional and social } \\
\text { preparedness of the graduate }\end{array}$} \\
\hline $\begin{array}{l}\text { Professional and subject-related } \\
\text { competency }\end{array}$ & $\begin{array}{l}\text { Integration of knowledge, cognitive } \\
\text { aspect (mastery of the knowledge- } \\
\text { based content), interdisciplinary } \\
\text { consistency }\end{array}$ & \\
\hline $\begin{array}{l}\text { Professional and activity-based } \\
\text { competency }\end{array}$ & $\begin{array}{l}\text { The experience of demonstrating the } \\
\text { competency in various activities: } \\
\text { information one, social and } \\
\text { technological one, managerial one, } \\
\text { project one, reflexive one, and } \\
\text { marketing one - for bachelors; the } \\
\text { scientific and research one and } \\
\text { methodological activity - for masters }\end{array}$ & \\
\hline Professional and personal competency & $\begin{array}{l}\text { Readiness for showing one's personal } \\
\text { property; readiness for actualization of } \\
\text { competencies; readiness for showing } \\
\text { one's competency; readiness for } \\
\text { interaction with other people etc.; } \\
\text { Attitude to oneself as to a personality, } \\
\text { life activity subject }\end{array}$ & \\
\hline
\end{tabular}

Source: Ukhabina (2008, p. 192-207).

Competences cannot be formed by study subjects only, be it even ones of the main professional educational program. Projecting a subject onto each competence and arguing it can be formed is a wrong way. A competence is a result of integration of educational technologies, organizational forms, methods, techniques and other learning and extracurricular activity 
performed in the so-called "competency-related space" which includes the professional environment, the territory within which education is performed, the activity, and the educational space.

The students' practical training is just the coupling link that unites the professional and educational environment of the competency-based space. Practice is generally known to always follow theory, so in educational process, too, it is a continuation, and frequently also a logical completion of a certain period of study. With regard to this, the architectonics of the curricula being the basic document for educational process has to be modulated in such a way as to lead to the formation of this or that competency, which was actually done at the second stage.

Given that practice is a logical completion of a certain period of study, the architectonics of the curricula undoubtedly has to be modulated in such a way as to lead to the formation of this or that competency. Table 2 "Recommendations on harmonization of the curriculum and modulating the competency- and practice-oriented disciplines of social activity bachelors" gives an example of harmonization of a social activity bachelor's curriculum.

Table 2

Recommendations on harmonization of the curriculum and modulating the competency-and practice-oriented disciplines of social activity bachelors

\begin{tabular}{|c|c|c|c|}
\hline & $\begin{array}{l}\text { Professional cycle and } \\
\text { subjects and subjects of } \\
\text { the elective parts of the } \\
\text { Federal state educational } \\
\text { standard }\end{array}$ & Kinds of practical training & Competences \\
\hline Module 1 & $\begin{array}{l}\text { Introduction to specialty; } \\
\text { Conflict management in } \\
\text { social work; } \\
\text { Professional ethic } \\
\text { foundations of social work; } \\
\text { Theory of communications } \\
\text { ("Culture of business } \\
\text { communication" tutorial); } \\
\text { Professional identity } \\
\text { tutorial; } \\
\text { Visiting of social institutions } \\
\text { of various directions of } \\
\text { activity within the practical } \\
\text { classes in the "Introduction } \\
\text { to specialty" subject }\end{array}$ & $\begin{array}{l}\text { Introductory training } \\
(2 \text { weeks })\end{array}$ & $\begin{array}{l}\text { To learn to establish contact } \\
\text { with the customer; } \\
\text { To master the skills of ethic } \\
\text { and business communication; } \\
\text { To know how to plan and use } \\
\text { one's work time sensibly; } \\
\text { To form an idea about the } \\
\text { structure of social institutions } \\
\text { and the content of } \\
\text { professional activity; } \\
\text { To be able to adapt to the } \\
\text { profession of one's choice } \\
\text { (social and personal } \\
\text { competences) }\end{array}$ \\
\hline Module 2 & $\begin{array}{l}\text { Sociology; } \\
\text { Psychology; } \\
\text { Social statistics; }\end{array}$ & $\begin{array}{l}\text { Educational practical } \\
\text { training } \\
(4 \text { weeks })\end{array}$ & $\begin{array}{l}\text { To have skills of collection, } \\
\text { analysis and systematization } \\
\text { of information; to develop a }\end{array}$ \\
\hline
\end{tabular}


Imagology (elective course);

"Psychology of personal

growth" workshop program of professional and literary growth

(social and personal

competences, general

scientific competences, general professional competences of the minimum width and depth, level I)

Module 3 Theory of social work; On-the-job training
Technology of social work; (10 weeks)
Management in social work;
Marketing and
advertisement of social
services;
Methods of research in
social work;
Legal support in social
work;
Individual and family
counseling;
Creative subjects;
Technologies of group
communication;
Projecting, forecasting and
modeling in social work;
Psychological and social
work with change - tutorial
on adaptation to changed
conditions

To have knowledge in the area of legal regulation in social work;

To know how to forecast and model the customer's problem situations; To learn to develop programs, cases, and projects of rendering assistance to the customer;

To be able to apply sociological research methods in practice; To master the ways, techniques and technologies used by a specialist counselor;

To develop managerial competences (social and personal competences, general scientific competences, general professional ones of the minimum width and depth, levels I-II)

\begin{tabular}{|c|c|c|c|}
\hline Module 4 & $\begin{array}{l}\text { Social work with children; } \\
\text { Social work with family; } \\
\text { Social work with the } \\
\text { disabled; } \\
\text { Social work with the old } \\
\text { age; } \\
\text { Problems of social work } \\
\text { with youth; } \\
\text { Content and technique of } \\
\text { pedagogical activity within } \\
\text { the system of psychological } \\
\text { and social work (social } \\
\text { pedagogy); } \\
\text { Content and technique of } \\
\text { social medical work }\end{array}$ & $\begin{array}{l}\text { Pre-graduation practice } \\
\text { ( } 8 \text { weeks) }\end{array}$ & $\begin{array}{l}\text { To be able to perform one's } \\
\text { professional activity } \\
\text { independently; } \\
\text { To be ready to adopt the } \\
\text { others' professional } \\
\text { experience and accept the } \\
\text { expressions of professional } \\
\text { openness; } \\
\text { To develop the skills of } \\
\text { development and application } \\
\text { of strategy of assistance for } \\
\text { various groups of customers; } \\
\text { To have an aspiration to } \\
\text { implement innovations; } \\
\text { To gain the skills of } \\
\text { development of one's own } \\
\text { techniques (methods) of } \\
\text { working with various groups } \\
\text { of customers; } \\
\text { To master the skills of testing } \\
\text { out (experimenting with) the }\end{array}$ \\
\hline
\end{tabular}


traditional and innovation techniques (methods) of social work with various groups of customers (social and personal competences, general scientific competences, and general professional ones of the maximum width and depth of all levels)

Source: Ukhabina T.E. (2008, p. 192-207).

Such modular practice-oriented education allows forming various types of competences consistently, making them more extended and profound from module to module.

Table 3

"Assessment criteria for the extent of formation of professional competences" presents the assessment criteria for competences to be mastered by the students during the modular practiceoriented education

\begin{tabular}{|c|c|c|c|c|c|c|c|}
\hline \multirow{2}{*}{ Competences } & \multicolumn{2}{|c|}{ Width } & \multicolumn{2}{|c|}{ Depth } & \multicolumn{3}{|c|}{ Levels } \\
\hline & minimum & maximum & minimum & maximum & I & II & III \\
\hline $\begin{array}{l}\text { Social and } \\
\text { technological } \\
\text { ones }\end{array}$ & $\begin{array}{l}\text { To master the } \\
\text { simplest social } \\
\text { technologies }\end{array}$ & $\begin{array}{l}\text { To master all } \\
\text { technologies }\end{array}$ & \multirow[t]{3}{*}{$\begin{array}{l}\text { To know how } \\
\text { to use known } \\
\text { technologies }\end{array}$} & \multirow{3}{*}{$\begin{array}{l}\text { To know how } \\
\text { to select the } \\
\text { optimum one } \\
\text { from several } \\
\text { technolo-gies, } \\
\text { to adapt it to } \\
\text { an individual } \\
\text { or a social } \\
\text { group, } \\
\text { situation, to } \\
\text { apply it, to } \\
\text { obtain a result, } \\
\text { and to show } \\
\text { initiative }\end{array}$} & \multirow{3}{*}{$\begin{array}{l}\text { To be } \\
\text { competent } \\
\text { towards a } \\
\text { certain } \\
\text { customer or } \\
\text { problem }\end{array}$} & \multirow{3}{*}{$\begin{array}{l}\text { To be } \\
\text { competent } \\
\text { towards a } \\
\text { social group } \\
\text { and several } \\
\text { problems }\end{array}$} & \multirow{3}{*}{$\begin{array}{l}\text { To be } \\
\text { competent } \\
\text { towards an } \\
\text { integrated } \\
\text { problem of a } \\
\text { territorial } \\
\text { community }\end{array}$} \\
\hline $\begin{array}{l}\text { Organizing, } \\
\text { managerial } \\
\text { and legal ones }\end{array}$ & $\begin{array}{l}\text { To perform } \\
\text { general } \\
\text { managerial } \\
\text { functions with } \\
\text { traditional } \\
\text { techniques }\end{array}$ & $\begin{array}{l}\text { To master the } \\
\text { modern social } \\
\text { management } \\
\text { methods }\end{array}$ & & & & & \\
\hline $\begin{array}{l}\text { Information } \\
\text { technological } \\
\text { ones }\end{array}$ & $\begin{array}{l}\text { To master the } \\
\text { main PC } \\
\text { programs }\end{array}$ & $\begin{array}{l}\text { To master all } \\
\text { PC programs } \\
\text { used in the } \\
\text { practice of } \\
\text { social work }\end{array}$ & & & & & \\
\hline
\end{tabular}




\begin{tabular}{|c|c|c|}
\hline Project ones & $\begin{array}{l}\text { To draw up the } \\
\text { simplest social } \\
\text { projects }\end{array}$ & $\begin{array}{l}\text { To draw up } \\
\text { elaborate } \\
\text { social projects, } \\
\text { to take part in } \\
\text { grant contests, } \\
\text { to organize the } \\
\text { implementa- } \\
\text { tion of the } \\
\text { projects with a } \\
\text { result obtained }\end{array}$ \\
\hline $\begin{array}{l}\text { Marketing } \\
\text { ones }\end{array}$ & $\begin{array}{l}\text { To master the } \\
\text { social market } \\
\text { services } \\
\text { research } \\
\text { methods }\end{array}$ & $\begin{array}{l}\text { To be able to } \\
\text { draw up a } \\
\text { marketing } \\
\text { plan, to } \\
\text { conduct a } \\
\text { study of } \\
\text { market, and to } \\
\text { develop a } \\
\text { social adverti- } \\
\text { sement }\end{array}$ \\
\hline Reflexive ones & $\begin{array}{l}\text { To master the } \\
\text { skills of } \\
\text { reflection and } \\
\text { self-reflection } \\
\text { on social } \\
\text { problems and } \\
\text { personal traits }\end{array}$ & $\begin{array}{l}\text { To master the } \\
\text { skills of } \\
\text { systemic } \\
\text { reflection and } \\
\text { self-reflection }\end{array}$ \\
\hline
\end{tabular}

Source: Ukhabina T.E. (2008, p. 192-207).

The extent of formation of competences has to be assessed by the practice training advisor both on the part of the higher education institution and by the receiving organization supervisor. It is the assessment of width, depth and formation level of competences - and not holding the formal documents confirming its completion - that shall determine the success of the practical training.

Description and purposes of the elements oriented to forming the educational process allows laying out the basic concept of higher education institution practical training (the bachelor's degree level) in the direction of social activity; it is given in Table 4 "The concept of higher education institution practical training".

Table 4

The concept of higher education institution practical training

\begin{tabular}{llll}
\hline Parts of the concept & Standards and & Recommendations for & Comments \\
\hline
\end{tabular}




\begin{tabular}{|c|c|c|c|}
\hline & $\begin{array}{l}\text { methodological } \\
\text { materials }\end{array}$ & implementation & \\
\hline $\begin{array}{l}\text { Objectives of the } \\
\text { practical training }\end{array}$ & $\begin{array}{l}\text { Provision on the } \\
\text { students' or learners' } \\
\text { practical training }\end{array}$ & $\begin{array}{l}\text { Objectives of all kinds of } \\
\text { practical training should be } \\
\text { worded in line with the } \\
\text { universal and professional } \\
\text { competences. } \\
\text { The objectives of each } \\
\text { practical training kind should } \\
\text { be up to certain width, depth } \\
\text { and level of the extent of } \\
\text { formation of a competence. }\end{array}$ & $\begin{array}{l}\text { The available provisions have to } \\
\text { be translated into the language of } \\
\text { quality management and } \\
\text { competency-based approach. } \\
\text { The influence of today's standards } \\
\text { on the practical training has to be } \\
\text { reduced to a minimum. } \\
\text { Each university has to have free } \\
\text { reserves for increasing the } \\
\text { duration of practical training (at } \\
\text { the expense of the scope of } \\
\text { optional hours of students' choice). } \\
\text { The emphasis in the curriculum } \\
\text { architectonics has to be placed on } \\
\text { the practice-oriented, tutorial and } \\
\text { developing kinds of classes. }\end{array}$ \\
\hline $\begin{array}{l}\text { Practical training } \\
\text { system subjects }\end{array}$ & $\begin{array}{l}\text { Methodological } \\
\text { guidelines on } \\
\text { completion of all kinds } \\
\text { of practical training. } \\
\text { Provision on the } \\
\text { practical training } \\
\text { board. } \\
\text { A list of practical } \\
\text { training places. } \\
\text { Assessment criteria for } \\
\text { institutions - places of } \\
\text { practical training. } \\
\text { Requirements for } \\
\text { practical training } \\
\text { supervisors }\end{array}$ & $\begin{array}{l}\text { It is expedient to conduct } \\
\text { certification of supervisors } \\
\text { and places of practical } \\
\text { training (via the rating and } \\
\text { criteria for places of practical } \\
\text { training). }\end{array}$ & $\begin{array}{l}\text { The requirements for institutions } \\
\text { and supervisors have to be } \\
\text { stipulated in the contract and } \\
\text { Provision on practical training. }\end{array}$ \\
\hline Functions & $\begin{array}{l}\text { Provision on practical } \\
\text { training. } \\
\text { Methodological } \\
\text { guidelines. } \\
\text { Diary of a trainee } \\
\text { student. } \\
\text { Individual assignment. }\end{array}$ & $\begin{array}{l}\text { The objectives of practical } \\
\text { training (competences) must } \\
\text { be at the head of practice- } \\
\text { oriented modules. } \\
\text { Introduction of other forms of } \\
\text { practical trainings is } \\
\text { advisable. }\end{array}$ & $\begin{array}{l}\text { Lectures and seminars have to be } \\
\text { oriented to not only knowledge } \\
\text { acquisition but also to formation } \\
\text { of competences. }\end{array}$ \\
\hline $\begin{array}{l}\text { Cooperation with } \\
\text { places of practical } \\
\text { training }\end{array}$ & $\begin{array}{l}\text { Three-party contract. } \\
\text { Program of further } \\
\text { training seminars for } \\
\text { practical training } \\
\text { supervisors }\end{array}$ & $\begin{array}{l}\text { The qualification of practical } \\
\text { training supervisors should be } \\
\text { enhanced at seminars. The } \\
\text { liabilities of trainees and } \\
\text { supervisors should be added } \\
\text { to the three-party contract as } \\
\text { well as the extent of their } \\
\text { responsibility and the } \\
\text { assessment mechanisms for } \\
\text { work of all subjects. }\end{array}$ & $\begin{array}{l}\text { It is advisable to agree the project } \\
\text { assignments for practical trainings } \\
\text { with the institutions. }\end{array}$ \\
\hline $\begin{array}{l}\text { Assessment of } \\
\text { results }\end{array}$ & $\begin{array}{l}\text { Self-assessment } \\
\text { questionnaire form. }\end{array}$ & $\begin{array}{l}\text { Sections containing the } \\
\text { assessment of professional }\end{array}$ & $\begin{array}{l}\text { The experience of European } \\
\text { higher education institutions has }\end{array}$ \\
\hline
\end{tabular}




$\begin{array}{ll}\begin{array}{l}\text { Diary of a trainee } \\ \text { student. }\end{array} & \begin{array}{l}\text { and personal growth during } \\ \text { the practical training and } \\ \text { Report on practical } \\ \text { reflection should be }\end{array} \\ \begin{array}{l}\text { introduced in the report. } \\ \text { Assessment criteria. }\end{array} & \begin{array}{l}\text { The assessment and self- } \\ \text { assessment should be oriented } \\ \text { to the extent of formation of } \\ \text { competences. }\end{array}\end{array}$

Source: Ukhabina T.E. (2008, p. 192-207).

The concept suggested determines the practical training organization system elements: goals set associated with width, depth and level of competences; subjects performing the practical training; the content and management of all kinds of practical training as reflected in the standard and toolkit documentation.

The system-building factor of the presented concept are the competences / competencies of graduates, for it is these that determine their competitiveness, professional and personal destiny, the opportunity to get actively included into the new system of social relationships and values in line with the requirements of the new economy.

\section{Conclusion}

The organization of practical training remains one of the problem niches in not only the Russian education but also in the European one. This is confirmed by the opinions of the German employers about the young employees' ability to apply the obtained theoretical knowledge in practice quoted in the paper as well as communication with the foreign and Russian colleagues. The dramatic change of social and economic situation in post-Soviet Russia necessitated making essential modifications. The Soviet "knowledge-based" education model, though highly efficient under the plan-organized stable society, turned out to be unsuitable for preparing the specialists for a rapidly developing controversial society that is vulnerable to actions of the global world. The knowledge ceased to be an advantage of the chosen ones; what became crucial is the ability to use it in practice in order to maximize the results yielded by any activity. The so-called competency-based approach came to be used as such a tool. This has already been implemented to a sufficient extent in the Russian education practice as well.

The subject-related concept of students' practical training allows uniting the components of two approaches, the conventional knowledge-based one and the activity-based one, which reflects the consistency and target orientation to the development of the Russian education up to the requirements of educational space globalization, labor markets expansion, and the universal 
history logging and IT-penetration. Quite important is also the fact that the implementation of the presented conceptual model, its data sheets, allows shaping not only professional but also reflexive competences that promote personal development and self-education, which is crucial in conditions of humanization of education and the society as a whole. 


\section{References}

Auvinen, P. (2006). Curriculum reform and competence definitions at Finnish Universities of Applied Sciences. URL: http://www.ncp.fi/etcts

Bundesarbeitsgemeinschaft der Praxisämter (2005). URL: https://bagprax.sw.eah-jena.de

Bundesarbeitsgemeinschaft der Praxisämter (2006). URL: http://bagprax.sw.fhjena.de/texte/Bag_Praxisorientierung_februar_2007.pdf

Demchenkova, S.A. (2011). Main approaches to interpretation of the notions of "competence" and "competency" abroad and their content. Bulltein of Tomsk State Pedagogical University, 13, 243-246.

Degterev, V.A. (2008). The development of competences or traditional training. In: Conceptualization of students' practical training within the Bologna criteria. Materials of the project. Tyumen: Publishing House of the Institute for Service and Management SEE HVE TSOGU, 103-113.

Doel, M. \& Shardlow, S.M. (2004). Modern social work practice. Aldershot, Hamshire: Ashgate.

Erbilgin, E. (2017). A comparison of the mathematical processes embedded in the content standards of Turkey and Singapore, Research in Social Sciences and Technology, 2 (1), 5374.

Eremin, A.V., Zoroastrova, I.V. \& Suchkova, E.O. (2015). Identification of key competences of higher education institution graduates. Studia Humanitatis. An international digital scientific journal, 4. URL: http:// st-hum.ru/journal/no-4-2015

Haedrich, B. (1967). Zur Berufsbildung der Sozialarbeiter in Deutschland. Entwicklungen und gegenwärtiger Stand. Dissertation. München.

Heimann, K. (2008). Bachelor hat Akzeptanzprobleme in der Wirtschaft. URL: http://neu.igmetall-wap.de/node/2504,2008

Hoffmann, M. (2017). An exploratory study: mobile device use for academics, Research in Social Sciences and Technology, 2 (1), 18-52.

Jugendministerkonferenz (2006). JMK: Top 6. Staatliche Anerkennung von Ausbildungsabschlüssen im sozialen Bereich im Kontext der Hochschul- und Studienreform. O.O. 2006, Protokoll der Jugendministerkonferenz am 18./19.5.2006 in Hamburg. 
Kenna, J.L. \& Poole, C.M. (2017). Social Science Pre-Service Teachers' Preparation to Teach About Asia: A Research Study. Journal of Social Studies Education Research, 8(1), 93114.

Kolb, A. \& Kolb, D.A. (1984). Experiential Learning as the source of learning and development. New Jersey: Prentice Heat. URL: https://pdfs.semanticscholar.org/f6ec/20a7a3150822140be7466353d0de572cc4bb.pdf

Lopatin, L.N. (2008). The quality of the Soviet higher education system -myths and reality. Questions of Education, 4, 186-193.

Martincová, J. \& Andrysová, P. (2017). Professional preparation of students of social pedagogy in the Czech Republic. Journal of Social Studies Education Research, 8(1), 47-68.

Mathews, S.A. (2016). Using Digital Participatory Research to Foster Glocal Competence; Constructing Multimedia Projects as a Form of Global and Civic Citizenship, Journal of Social Studies Education Research, 7(2), 1-29.

Mauch, J. \& Tarman, B. (2016). A historical approach to social studies laboratory method. Research in Social Sciences and Technology, 1(2), 55-66.

Merten, R. (2000). Sozialarbeit als Studium: einphasig oder zweiphasig? In: Archiv für Wissenschaft und Praxis der sozialen Arbeit, 1, 51-72.

Paleeva, O.A. (2013). Competency-based approach in higher education of Germany. Bulletin of N.I. Lobachevskiy Nizhny Novgorod University, 1, 24-29.

Schmitt, Ch. (2007). Praxisorienierung - Staatliche Anerkennung - Berufspraktikum. Auslaufmodelle oder Elemente der Qualitätssicherung in Ausbildungszusammenhängen der Sozialarbeit im Zeichen von Bologna. Lüneburg.

Sitaeva, I.N. \& Chupris A.S. (2015). Competency-based interpretation of the results of professional education: history and objectives. Bulletin of I. Kant Baltic federal university, $5,62-68$.

Soland, J., Hamilton, L. \& Stecher, B. (2013). Measuring 21 Century Competencies Guidance for Education - Asia Society. URL: http//goo.gl/89TMHy

Social psychology of education (2005). Ed. A.N. Sukhov Moscow: Akademy publishers. Teichler, U. (2005). Hochschulsysteme und Hochschulpolitik. Quantitative und strukturelle Dynamiken, Differenzierungen und der Bologna-Prozess. Munter. URL: 
http://readrate.com/rus/books/hochschulsysteme-und-quantitativ-strukturellehochschulpolitik

Toffler, E. (2002). The Futurists. Moscow: AST Publishers.

Ukhabina, T.E. (2008). Competency-based model of a "Social work" specialty graduate. In: Conceptualization of students' practical training within the Bologna criteria. Materials of the project. Tyumen: Publishing House of the Institute for Service and Management SEE HVE TSOGU, 192-207.

Verein für öffentliche und private Fürsorge e.V. (2004). Stellungnahme des Deutschen Vereins zur Staatlichen Anerkennung von Sozialarbeiterinnen und Sozialarbeitern. In: Nachrichtendienst des Deutschen Vereins, 2, 39-40.

White, R.W. (1959). Motivation Reconsidered: The Concept of Competence. Psychological Review, 66, 297-333.

Zeer, E.F. (2000). Key qualifications and competences in student-centered professional space. Education and science, 3, 90-120.

Zimnyaya, I.A. (2003). Key competences-new paradigm of education results. Higher Education Yesterday and Today, 5, 34-42. 